\title{
Structure, composition and carbon stocks of woody plant community in assisted and unassisted ecological succession in a Tamaulipan thornscrub, Mexico
}

Eduardo Alanís-Rodríguez', Víctor M. Molina-Guerra², Alejandro Collantes-Chávez-Costa ${ }^{3}$, Enrique Buendía-Rodríguez ${ }^{4}$, Arturo Mora-Olivo ${ }^{5}$, Laura Sánchez-Castillo6 ${ }^{6 *}$ and Alejandro G. Alcalá-Rojas ${ }^{7}$

\begin{abstract}
Background: Ecological restoration is a process that helps the recovery of an ecosystem that has been degraded, damaged or destroyed. The success of restoration actions depend on the understanding of the processes, mechanisms and factors that guide vegetation dynamics. The restoration of plant communities can be made by unassisted (passive restoration, where the community recover by itself) and assisted (active restoration) ecological succession. It is imperative to know the scope of both types of activities to guide future restoration actions by evaluating the properties and functioning of the intervened communities.
\end{abstract}

Methods: Variance analysis of the carbon (C) stocks, basal area, canopy area, Shannon-Weaver index values, specific richness and abundance of three Tamaulipan thornscrub communities (assisted natural succession area, unassisted natural succession area and control area) was performed. Furthermore, a similarity analysis between the sampling areas using the floristic composition (abundance) was performed.

Results: In total, 11 families, 17 genera and 20 species of vascular plants were registered. The richness of species and abundance ranked as follows per area: assisted ecological natural succession > control > unassisted ecological natural succession. The species composition between sampling areas showed a low number of common species between plant communities.

Conclusions: The values of species richness, diversity, abundance, basal area, and canopy area of the assisted natural succession vegetal community was statistical similar to the control plan community. The values of C stocks showed that assisted ecological succession could recover not only structure and composition attributes but also this key ecosystem property.

Keywords: Ecological restoration, Plant communities, Post-agricultural restoration, Xerophytic scrub, Community ecological properties

*Correspondence: laura.sanchez@uat.edu.mx

${ }^{6}$ Facultad de Ingeniería Y Ciencias, Centro Universitario, Universidad Autónoma de Tamaulipas, CP 87120 Ciudad Victoria, Tamaulipas, México

Full list of author information is available at the end of the article

\section{Background}

Ecological restoration is a process that helps the recovery of an ecosystem that has been degraded, damaged or destroyed [61]. Aims to recover the biodiversity and ecosystem services, considering the ecological, socioeconomic and cultural processes [56]. Recently, the original author(s) and the source, provide a link to the Creative Commons licence, and indicate if changes were made. The images or other third party material in this article are included in the article's Creative Commons licence, unless indicated otherwise in a credit line to the material. If material is not included in the article's Creative Commons licence and your intended use is not permitted by statutory regulation or exceeds the permitted use, you will need to obtain permission directly from the copyright holder. To view a copy of this licence, visit http://creativecommons.org/licenses/by/4.0/. 
recovery of disturbed landscapes and biological communities is becoming a priority in many regions of the world [5]. However, the results of restoration are different and depends largely on the conditions and type of restoration action used to achieve the desired success.

In general terms, ecosystem ecological restoration can be classified into two types according to the strategy used: passive restoration where the ecosystem recovery by itself, like unassisted natural succession, and active restoration, where restoration activities are undertaken to accelerate the recovery of the ecosystem, like planting species to accelerate recovery in an assisted natural succession $[12,42,61]$. The unassisted ecological succession (passive restoration) can achieve good results in certain cases, but usually takes decades or centuries and generally does not guarantee a composition of species like the original state [1]. On the contrary, the assisted ecological succession (active restoration), usually shows better results, allowing the establishment of a higher canopy that improves the ecological conditions of the ecosystems in less than ten years $[56,66]$. Regardless of the restoration chosen, it is imperative to carry out studies and actions that help ecological recovery in regions whose biological and ecosystem biodiversity is strongly threatened [32, 57, 58].

As mentioned on Linding-cisneros research on the challenges of a multicultural and megadiverse country like Mexico [30, 64], the government has promoted the restoration in natural protected areas and degraded communities. In this aspect, Tobon et al. developed a conceptual framework on the restoration of all terrestrial ecosystems, including xeric shrublands [64]. These plant communities occupy large areas in northern Mexico and in many cases the original vegetation has been eliminated to establish agricultural or livestock areas [6]. For this reason, restoration actions on shrublands such as the Tamaulipan thornscrub are key activities to recover and conserve vegetation structure and diversity $[4,50,65]$.

The Tamaulipan thornscrub is a plant community usually found on deep clay soils, plateaus, hillocks and plains between 200 and $500 \mathrm{~m}$ altitude, under the influence of warm and semi-warm climates [60]. It is restricted to northeastern Mexico and southern Texas, and its original distribution in these areas has been reduced by $70 \%$ and $90 \%$, respectively, due to changes in land use for agricultural and livestock purposes [7]. This scrub has a structure formed mainly by two strata, one shrubby $(2-5 \mathrm{~m}$ high) usually composed of thorny elements and another herbaceous that does not exceed the height of a meter [60]. It has a high species richness $(S=21 ;[33,37], S=29$ [24]) including species such as: Celtis pallida Torr. (Cannabaceae), Opuntia leptocaulis DC. (Cactaceae), Prosopis glandulosa Torr. (Fabaceae) Acacia rigidula Benth.
(Fabaceae) and Ruellia nudiflora (Engelm. \& A. Gray) Urb. (Acanthaceae), being some of these, important forestry and silvopastoral species [19].

Although it has been observed that the ecological restoration increases biodiversity and ecosystem services in general, results can be different for the different types of restoration and ecosystems $[10,26,56]$. Thus, studies that systematically evaluate the results of active and passive ecological restoration in the same location after the same disturbance, related to the recovery of structure, diversity and provision of ecosystem services such as carbon sequestration, are important to be undertaked in differents ecosystem [26, 39, 53, 56]. Furthermore, although the Tamaulipan thornscrub has been intensively studied in recent years [24, 33, 53, 59], only a few investigations have evaluated the structure and composition of woody plan community after agricultural activity in this ecosystem. Until now, research efforts on the Tamaulipan thornscrub have focused on timber volume production $[20,47]$, species survival $[4,65]$ or leaf and litter biomass [48].

The objective of this study is to evaluate the structure and composition such as species richness, diversity, abundance, basal area, canopy area and carbon (C) stocks of woody plant communities of the Tamaulipan thornscrub and to compare the differences in these ecosystem attributes between assisted/unassisted ecological succession and control areas. Our hypothesis is that the assisted ecological succession and control areas will show similar vegetation structure and composition, as well as in terms of the ecosystem service carbon sequestration.

\section{Methods}

\section{Study area}

The study area is located in the municipality of Pesquería, Nuevo Leon (Northeast Mexico, Fig. 1), 2545'17.78' north latitude and $99^{\circ} 58^{\prime} 01.40^{\prime \prime}$ west longitude. The climate is very dry to semi-warm (BWhw) according to the classification of Köppen (modified by Enriqueta Garcia) [23], the average annual temperature is between 20 and $21{ }^{\circ} \mathrm{C}$. Soil types on the site are: xerosol, castañozem, feozem, regosol and minimally, fluvisol, vertisol, and rendzina [4], The average annual rainfall on the study area is $550 \mathrm{~mm}$ and an altitude of $330 \mathrm{~m}$.a.s.l. The representative plant community consists mainly of Tamulipan thornscrub with shrubs as secondary vegetation mainly dominated by Acacia farnesiana [3].

\section{Vegetation analysis}

In November of 2017, the structure and composition of woody plant communities were investigated through a floristic composition and diversity evaluation on three areas: a control area, an assisted ecological succession 


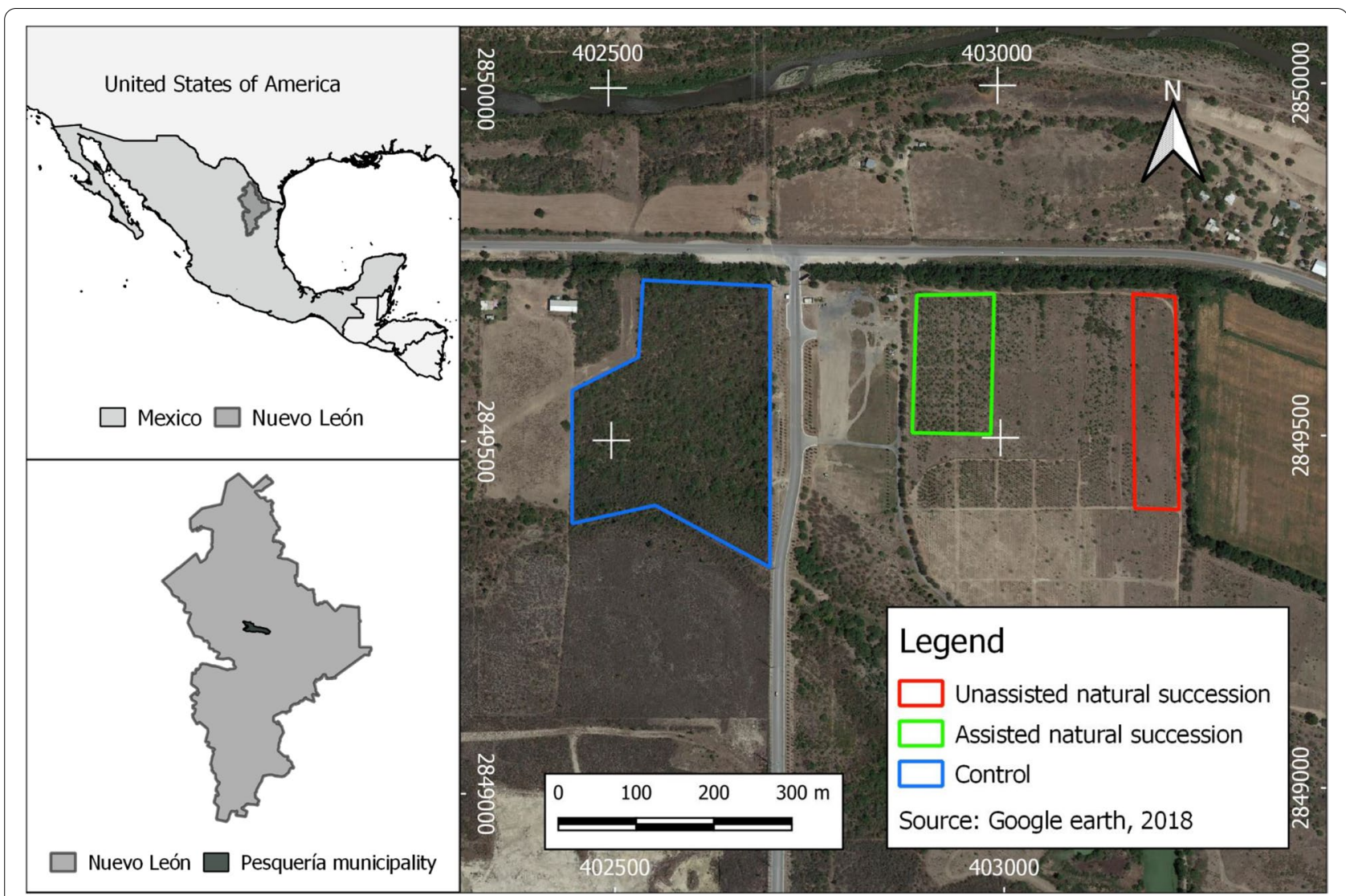

Fig. 1 Study area location

area and an unassisted ecological succession area. The species registered were identified at the species level by qualified personnel of the Faculty of Forest Science of the Universidad Autonoma de Nuevo León (UANL). Their scientific names were validated against names in Tropicos (http://www.tropicos.org) and IPNI (http://www.ipni. org) databases.

The control area is composed of a Tamaulipan thornscrub climax community where there are not records of productive activity involving total or partial removal of vegetation (such as: livestock, slaughter, agriculture etc.). The assisted ecological succession areas have a history of agricultural use and received an assisted ecological succession treatment after abandonment in September of 2009. The unassisted ecological succession area has the same history of use and abandonment as the previous mentioned site but assisted ecological succession actions were not performed. The agricultural activity mentioned on both assisted and unassisted areas consisted of plantations of oats, wheat and corn for approximately two decades (1989-2009). The crops were sowed in a rotating manner and irrigated by a gravity-driven water channel. Planting and harvesting activities were made using a farm tractor. All areas had similar characteristics: vertisol type of soil, $310 \mathrm{~m}$. in elevation, the slope of $<3 \%$.

The assisted ecological succession consisted of reforestation with native species in April of 2010. The species used for reforestation were rescued from a land-use changed area, authorized by SEMARNAT (Secretariat of Environment and Natural Resources) due the absence of nurseries producing the high diversity of native species of Tamaulipan thornscrub. The rescue started with the selection of abundant individuals of smaller size: arboreal and shrub species with heights from 0.5 to $2.0 \mathrm{~m}$ and basal diameters from $0.5-1.5 \mathrm{~cm}$ were considered, and each individual was labeled with: the common name, serial number and coordinates in where it was found. The specimen extraction process started with the pot preparation, using plastic paper to cover the roots to prevent from exposure and soil crumbling, then, the individuals were moved to a different site by trailer. When the plantation actions started, the specimens were placed in the strains and the plastic paper removed, fungicide and root promoter were applied, and plant tutor sticks were placed followed by the first irrigation. The plantation area was periodically cleaned of weeds. The plantation was 
made using a triangular plantation system with a distance of $1.5 \mathrm{~m}$ between individuals and lines having a plantation density of $992 \mathrm{n} \mathrm{ha}^{-1}$. The process scheme can be observed in Additional file 1: Appendix.

An analysis of preliminary samples obtained for the study area was carried out seven years before (September 2017) to obtain a value of sampling units needed to register $95 \%$ of the richness of each community. For doing so, we used the equation of Mostacedo and Fredericksen [43]:

$$
n=\frac{t^{2} * C V^{2}}{E^{2}+\frac{t^{2} * C V^{2}}{N}}
$$

where $n$ is the adequate number of sampling areas, $E$ is the error (20\%), $t$ is the extracted value of $t$ student tables $(p<0.05), N$ is the total sampling unites and CV the variation coefficient. According to this mathematical model, 12 sampling plots of $10 \times 10 \mathrm{~m}\left(100 \mathrm{~m}^{2}\right)$ were randomly established in each area. A census of all plant species higher than $10 \mathrm{~cm}$ was carried out. Dendrometric measurements of total height $(\mathrm{h})$, basal diameter $\left(d_{0.10}\right)$, which was estimated from the basal areas of all the ramifications, (cross sectional area) and canopy diameter $\left(d_{\text {canopy }}\right)$ were carried out on each individual. Diametric classes (5, $10,15,20,25,30,35$ and $>35$ ) were established.

\section{Data analysis}

We analyzed the relative abundance, dominance, and frequency of plant species to estimate their importance value index $[43,44]$. The absolute abundance was calculated using the number of individuals found on the plots and was extrapolated to hectare, using the following formula: $A_{i}=N_{i} / S$, where $A_{i}$ is the absolute abundance of species $i, N_{i}$ is the number of individuals of species $i$, and $S$ the sample surface (in hectares). The relative abundance of species was calculated using the equation: $A r_{i}=\left(A_{i}\right)$ $\left.\Sigma A_{i}\right)^{*} 100$, where $A r_{i}$ is the relative abundance and $\Sigma A_{i}$ is the total abundance of species $i$. To estimate dominance the basal area for each individual was calculated. The basal area was calculated with the formula $A=\pi / 4 * d^{2}$, where $A$ is the basal área, $\pi$ is a constant value of 3.14 , and $d$ is the basal diameter $\left(d_{0.10}\right)$. The absolute dominance is $D_{i}=A b_{i} / S$, where $D_{i}$ is the absolute dominance of species $i, A b_{i}$ is the basal area (in square meters) of species $i$, and $S$ the sample surface (in hectares). The relative dominance was calculated using the equations $D r_{i}=\left(D_{i} /\right.$ $\left.\Sigma D_{i}\right)^{*} 100$, where $D r_{i}$ is the relative dominance of species $i$ total dominance over and $\Sigma D i$ is the total dominance of species. The relative frequency is $F_{i}=\left(F_{i} / \Sigma F_{i}\right) 100$, where $F r_{i}$ is the relative frequency of species $i$ over the total frequency, $F_{i}$ is the number of plots that present the species $i$ and $\Sigma F_{i}$ is the total frequency of all species. The importance value index (IVI) was calculated as follows: IVI $=(\Sigma$
$\left.A r_{i}+D r_{i}+F r_{i}\right) / 3$, where $A r_{i}$ is relative abundance, $D r_{i}$ is relative dominance and $\mathrm{Fr}_{i}$ is relative frequency [43, 44].

To determine the alpha diversity of the studied communities, two indices were used: Margalef (DMg), which is based on the quantification of the number of species present (specific wealth), and Shannon $\left(\mathrm{H}^{\prime}\right)$, which refers to the numerical structure of the community or proportional distribution of the abundance of each species [40]. The Margalef index was calculated with the following equation $\mathrm{DMg}=(\mathrm{S}-1) / \ln (\mathrm{N})$, where $S$ is the number of species present and $N$ the total number of individuals.

The similarity assessment between the sampling areas was performed using the floristic composition (abundance). For this purpose, a hierarchic cluster analysis was carried out using the block-distance measure and Ward's clustering method, graphing it on a similarity dendrogram. Statistical analyzes were performed using the software $\mathrm{R}$ ver. 2.6.0. with cluster package [54]. In addition, the communities (control, assisted ecological succession and unassisted ecological succession area) were explored by Bray-Curtis ordination analysis [9]. The analysis is based on an algorithm allowing analyzing the similarity of the communities sampled by calculating the percentage of similarity $(0-100 \%)$ in a distance measure [8]. The results were presented in a dendrogram and the statistical analyzes were performed using the software package BioDiversity Professional Ver. 2 [38].

\section{Carbon stocks}

To determine the carbon stocks of the arboreal and shrub species of Tamaulipan thornscrub, first, the aerial biomass was determined using the local allometric equation $(r=0.80)$. [45].

$$
\begin{aligned}
\text { BT }= & \left(0.026884+0.001191 * \mathrm{~d}^{2} 2 \mathrm{~h}+0.044529 * \mathrm{~d}-0.01516 * \mathrm{~h}\right) \\
& +\left(1.025041+0.023663 * \mathrm{~d}^{2} \mathrm{~h}-0.17071 \mathrm{~h}-0.09615 * \ln (\mathrm{h})\right) \\
& +\left(-0.43154+0.011037 * \mathrm{~d}^{2} \mathrm{~h}+0.113602 * \mathrm{~d}+0.307809 * \ln (\mathrm{d})\right) .
\end{aligned}
$$

where, $\mathrm{BT}=$ total aerial biomass, $\mathrm{d}=$ basal diameter and $\mathrm{h}=$ total height.

The arboreal and shrub species in the Tamaulipas thornscrub do not have allometric equations that assessment of carbon stock, therefore, the carbon stock was calculated using the 0.454 factor according to [68], where it is interpreted that $45.4 \%$ of the biomass aerial corresponded to carbon stocks.

Statistical tests using IBM SPSS Statistic ver. 19 ๑ [69] were carried out to verify that the assumptions of the residuals were fulfilled, normality using the ShapiroWilk test and homogeneity of variances by the Levene test, both with a significance value $(p<0.05)$. Since they fulfilled the assumptions, a generalized linear model 
(glm) was used with a Gaussian distribution function for Shannon-Weaver index values, specific richness, abundance and an analysis of variance (ANOVA) of one factor (area) was performed for carbon stock, basal area and canopy area. The Duncan test was used to determine if there were significant differences $(p<0.05)$ of the variables analyzed per area.

\section{Results}

In total, 11 families, 17 genera and 20 species of vascular plants were registered. Fabaceae was the family with more species with 9, followed by Boraginaceae with two. The Additional file 2: Appendix II shows the floristic inventory of the study areas in detail.

The control area had 13 species, where, Cordia Boissieri A. DC., Parkinsonia texana (A.Gray) S. Watsonhad and Acacia rigidula were dominant. The assisted ecological succession area had 12 species with species like Acacia farnesiana, Leucophyllum frutescens (Berland.) I.M. Johnst, Cordia boissieri. The unassisted ecological succession area registered six species; Acacia farnesiana, Leucophyllum frutescens, and Prosopis glandulosa were the most representative species in this area.

The richness of species using the Margalef index showed significant differences between the studied areas. The assisted ecological succession area showed greater richness with $5.58 \pm 0.43$ (average \pm standard deviation), followed by the control area $(4.41 \pm 0.37)$ and unassisted ecological succession area $(0.91 \pm 0.25)$. The values of the Shannon index in the assisted ecological succession areas $(0.64 \pm 0.04)$ and control area $(0.54 \pm 0.04)$ showed no significant differences, and both were higher than the unassisted ecological succession $(0.30 \pm 0.01)$ (Fig. 2).

The Table 1 showed the results of the GLM, $X^{2}$-test and the freedom degrees for each sampling area. The Shannon Index (81.429), Species richness (Margalef index) (68.411) and Abundance (155.394) the values of $\chi^{2}$ were less than $\chi^{2}$-table (27.59) at alpha $(\alpha=0.05)$, therefore, the null hypothesis (equality of means) was rejected. This means that the observed data fit the theoretical distribution. The results of ANOVA for basal area and canopy area were showed in the Table 1 and the F-statistic value were 15.839 and 33.407 , respectively; therefore, rejected $\mathrm{HO}(\mathrm{H} 0: \mu 1=\mu 2=\mu 3)$ because these values were $>3.32$ (F-table). Thus, there were difference statistically significant at $\alpha=0.05$ between sampling areas (Control area, assisted ecological succession and unassisted ecological succession area). In the posthoc test and their $p$-values, the mean values of the Control area and assisted ecological succession do not have significantly different, but the mean values of the assisted ecological succession and unassisted ecological succession area have significantly different for Shannon
Index, Species richness (Margalef index), Abundance and basal area (Fig. 2A, B, C and D). Only canopy area had significantly different between three sampling areas (Fig. 2F). Regarding the analysis of diametric classes of each area, the control area was the only one showing individuals equal to or greater than $35 \mathrm{~cm}$ and registered the biggest number of individuals in the $10 \mathrm{~cm}$ category (more than $50 \%$ of the individuals), while the assisted ecological succession showed more than $50 \%$ in the $5 \mathrm{~cm}$ category. In the three areas, the greatest number of individuals was concentrated in the categories of 5,10 and $15 \mathrm{~cm}$ respectively (Table 2 ).

Absolute density, dominance and importance value index of all the studied areas are shown in Table 3. The abundance values of the control area $\left(1175 \pm 121 \mathrm{~N} \mathrm{ha}^{-1}\right)$ and assisted ecological succession $\left(1416 \pm 178 \mathrm{~N} \mathrm{ha}^{-1}\right)$ areas were higher than those of the unassisted ecological succession area (100 \pm 27$)$. The basal area of the vegetation communities of the assisted ecological succession and control area showed statistical similarity $(7.86 \pm 1.30$ and $8.31 \pm 1.03$ $\mathrm{m}^{2} \mathrm{ha}^{-1}$ respectively) and were significantly higher than the unassisted ecological succession community $\left(0.85 \pm 0.74 \mathrm{~m}^{2} \mathrm{ha}^{-1}\right)$.

The canopy area of the individuals in the assisted ecological succession and control area showed statistical similarity. The control area showed overlap in the canopy area with $13,365 \pm 1470 \mathrm{~m}^{2} \mathrm{ha}^{-1}$ and the assisted ecological succession with $9298 \pm 880 \mathrm{~m}^{2} \mathrm{ha}^{-1}$, which is equivalent to $92 \%$ coverage. The unassisted ecological succession community presented $1039 \pm 777 \mathrm{~m}^{2} \mathrm{ha}^{-1}$, equivalent to the $10 \%$ coverage.

The composition of species per sampling area is showed in Fig. 3. After clustering control area (plots 1-12) five sites were grouped in unassisted ecological succession area (plots 1, 6-8 and 11) and one in the assisted ecological succession area (4). While the unassisted ecological succession area (plots 25-36) showed similarity with the other areas, adding plots $1,6-8,11$, 14-18, 22-23. The assisted ecological succession area (13 to 24 ) showed a lower similarity in species composition, only having four of the original sampling plots (13, $19,20,21)$, and adding another one (4). This means that the sampling areas contain de majority of the sites with their original category (Control area, assisted ecological succession and unassisted ecological succession area), for this reason the analysis of similarity between communities was carried out. The species composition analysis showed few common species between plant communities. From the numerical classification, a group formed by control and assisted ecological succession areas was distinguished with $23 \%$ of similarity, while the similarity with unassisted ecological succession area is $16 \%$ (Fig. 4). 


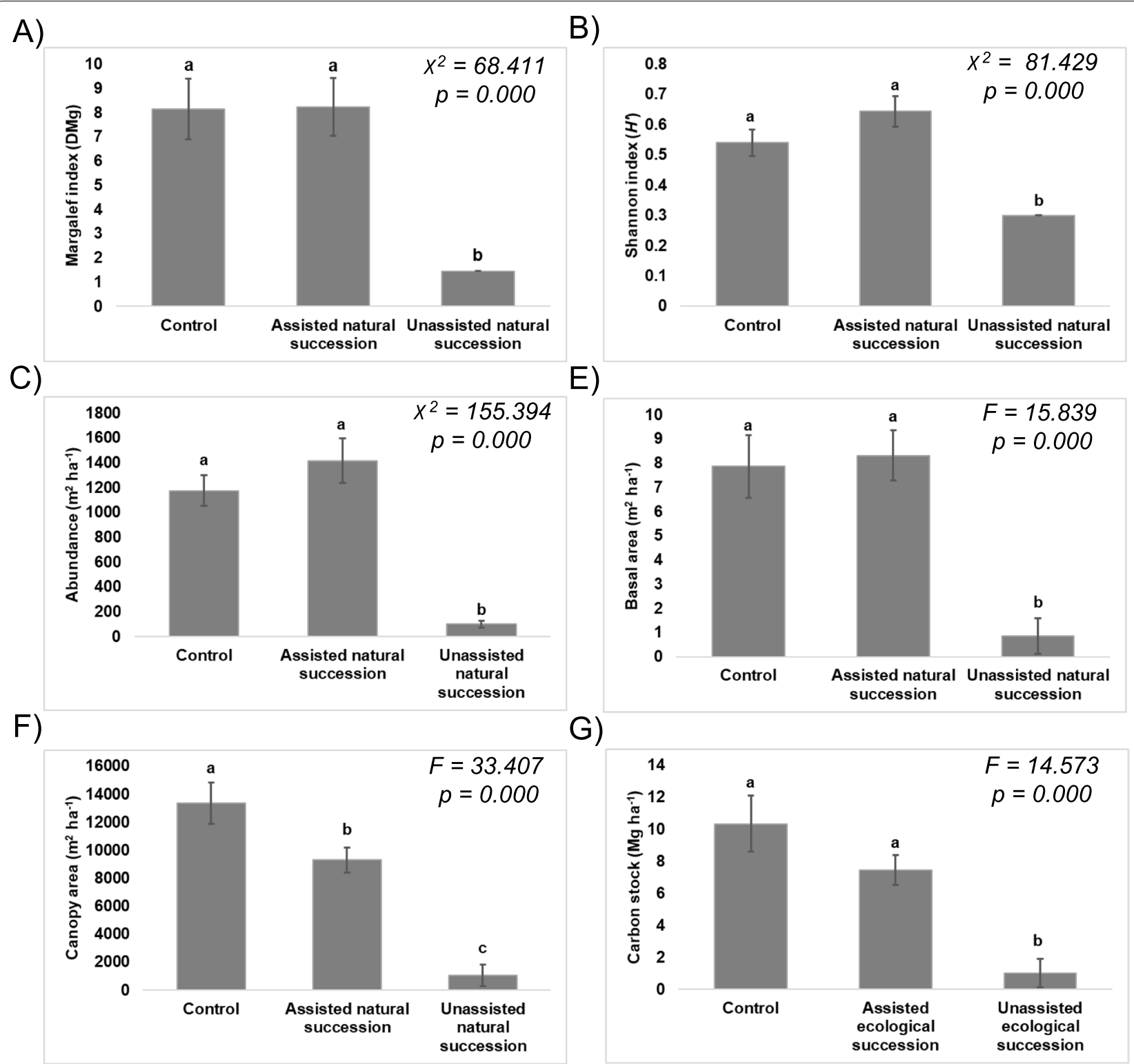

Fig. 2 A) Margalef index $\left(D_{M g}\right)$, Shannon index $\left(\mathrm{H}^{\prime}\right)$ Abundance $\left(\mathrm{m}^{2}\right.$ ha $\left.{ }^{-1}\right)$, Basal area $\left(\mathrm{m}^{2}\right.$ ha $\left.{ }^{-1}\right)$, Plant cover $\left(\mathrm{m}^{2}\right.$ ha $\left.{ }^{-1}\right)$ and carbon stock $\left(M g\right.$ ha $\left.{ }^{-1}\right)$ of the evaluated communities. Means ( \pm standard error, $\mathrm{n}=12$ ) followed by different letters $(\mathrm{a}, \mathrm{b}, \mathrm{c})$ show significant differences at $P=0.05$ (Duncan test)

\section{Carbon stocks}

The results of ANOVA for carbon stocks are shown in the Table 1. The F-statistic value was 14.573; therefore, we rejected $\mathrm{H} 0 \quad(\mathrm{H} 0: \quad \mu 1=\mu 2=\mu 3)$ because $14.573>3.32$ (F-table). Thus, there was a statistically difference significant at $\alpha=0.05$ between sampling areas. In the post-hoc test, the mean values of the control area $\left(10.35 \pm 1.75 \mathrm{Mg} \mathrm{ha}^{-1}\right)$ and assisted ecological succession $\left(7.45 \pm 0.92 \mathrm{Mg} \mathrm{ha}^{-1}\right)$ do not showed significant statistical differences, but the mean values of the assisted ecological succession and unassisted ecological succession area $(0.99 \pm 0.88 \mathrm{Mg}$ ha- 1$)$ showed significant statistical differences for Carbon stock (Fig. 2G). More than $50 \%$ of the concentration of carbon stock registered in both control and assisted ecological succession area was centered in diameter categories from 5 to $20 \mathrm{~cm}$, in the unassisted ecological succession area the higher concentration of carbon was found in the $30 \mathrm{~cm}$ category. 
Table 1 Generalized linear model (glm) for Shannon-Weaver index values, specific richness, abundance, and analysis of variance (ANOVA) of one factor (area) was performed for carbon stock, basal area and canopy area

\begin{tabular}{|c|c|c|c|c|c|c|}
\hline & & & $d f$ & & Chi-squared & Sig \\
\hline \multicolumn{3}{|l|}{ Shannon index } & 17 & & 81.429 & .000 \\
\hline \multicolumn{3}{|l|}{ Species richness } & 8 & & 68.411 & .000 \\
\hline \multicolumn{3}{|l|}{ Abundance } & 18 & & 155.394 & .000 \\
\hline & & Sum of Square & df & Mean Square & $\mathrm{F}$ & Sig \\
\hline \multirow[t]{3}{*}{ Carbon stock } & Between Groups & 550.841 & 2 & 275.421 & 14.573 & .000 \\
\hline & Within Groups & 623.674 & 33 & 18.899 & & \\
\hline & Total & 1174.516 & 35 & & & \\
\hline \multirow[t]{3}{*}{ Basal area } & Between Groups & 419.906 & 2 & 209.953 & 15.839 & .000 \\
\hline & Within Groups & 437.442 & 33 & 13.256 & & \\
\hline & Total & 857.348 & 35 & & & \\
\hline \multirow[t]{3}{*}{ Canopy area } & Between Groups & $946,792,272.453$ & 2 & $473,396,136.227$ & 33.407 & .000 \\
\hline & Within Groups & $467,627,393.550$ & 33 & $14,170,527.077$ & & \\
\hline & Total & $1,414,419,666.003$ & 35 & & & \\
\hline
\end{tabular}

\section{Discussion}

Fabaceae showed the largest number of species in the study area. The representativeness of the Fabaceae family was also reported in previous studies carried out in North Mexico, where the family was identified as a big diversity group [15] in conserved areas, in secondary vegetation communities and assisted ecological succession communities $[2,25,35,39]$.

The diversity of Fabaceae is attributed to the ecological plasticity of the group, which contains species with different seed sizes, types of dormancy, germination rates [17, 27-29], longevities [11, 14], growth rates and patterns $[14,21]$ and tolerance to water scarcity and to nitrogen [3, 13, 24, 50]. All above mentioned factors allow members of the Fabaceae family to be present in different environmental conditions [16, 46, 55] influencing the existence of different compositions within

Table 2 Number of individuals per hectare in each diametric category

\begin{tabular}{llll}
\hline $\begin{array}{l}\text { Diameteric } \\
\text { category }\end{array}$ & $\begin{array}{l}\text { Control area } \\
\text { Ind / ha }\end{array}$ & $\begin{array}{l}\text { Assisted } \\
\text { ecological } \\
\text { succession area } \\
\text { Ind / ha }\end{array}$ & $\begin{array}{l}\text { Unassisted } \\
\text { ecological } \\
\text { succession area } \\
\text { Ind / ha }\end{array}$ \\
\hline 5 & 425 & 717 & 75 \\
10 & 517 & 383 & 0 \\
15 & 125 & 175 & 8 \\
20 & 58 & 108 & 8 \\
25 & 17 & 33 & 0 \\
30 & 8 & 0 & 8 \\
35 & 8 & 0 & 0 \\
$>35$ & 17 & 0 & 0 \\
Total & $\mathbf{1 1 7 5}$ & $\mathbf{1 4 1 7}$ & $\mathbf{1 0 0}$ \\
\hline
\end{tabular}

the same Tamaulipan thornscrub $[15,55]$. Factors such as propagules availability and ecological performance, along with the interactions between other taxonomic groups presented in the Tamaulipan thornscrub community are responsible of determining vegetation performance [52].

The comparison of richness and diversity of species between sites were similar to the values reported on previous studies [2, 25, 35]. The unassisted ecological succession area low richness and diversity of species can be largely attributable to the dominance of one or two taxa over others, which can be due the action of environmental filters limiting the presence of other species (e.g., low nitrogen content, insolation and drought) as suggested by [31].

The importance value index of the control area is similar to the values reported by [39] showing the characteristics of a mature community [18]. The presence of Cordia boissieri and Parkinsonia texana in a mature secondary vegetation community like in the control area has been reported by $[15,45]$. Those species are considered as pioneer species of early successional stages [11, 14], showing a life spectrum of 30-50 years [11, 14] which could explain why they exist in the control area. Besides, the rapid growth of $P$. texana, along with the high germination rate in share light conditions with C. boissieri [29], and the establishment capacity under shadow conditions suggested by its seed size. [30] could explain the Importance Value registered. Acacia rigidula has a higher germination rate than $C$. boissieri $[27,30]$, but the size of its seed suggests low tolerance to shade and rapid growth $[22,34]$, which could explain why it occupies the third important value index of the control area.

Regarding the secondary natural succession trajectory, the presence of Acacia farnesiana and Prosopis 
Table 3 Absolute density (number per hectare), absolute dominance (square meters per hectare), and importance value index (IVI, percent) of the three areas evaluated

\begin{tabular}{|c|c|c|c|c|c|c|c|c|c|}
\hline \multirow[t]{3}{*}{ Specie } & \multicolumn{3}{|l|}{ Control } & \multicolumn{3}{|c|}{ Assisted natural succession } & \multicolumn{3}{|c|}{ Unassisted natural succession } \\
\hline & Density & Dom & & Density & Dom & & Density & Dom & \\
\hline & $\mathrm{N} \mathrm{ha}^{-1}$ & $\mathrm{~m}^{2} \mathrm{ha}^{-1}$ & IVI & $\mathrm{Nha}^{-1}$ & $\mathrm{~m}^{2} \mathrm{ha}^{-1}$ & IVI & $\mathrm{N} \mathrm{ha}^{-1}$ & $m^{2} h a^{-1}$ & IVI \\
\hline Acacia farnesiana & * & $*$ & * & 374 & 544 & 34.3 & 38 & 113 & 56.6 \\
\hline Acacia rigidula & 181 & 189 & 16.7 & 11 & 16 & 2.3 & * & * & * \\
\hline Celtis pallida & 4 & 15 & 1.1 & * & * & * & * & * & * \\
\hline Cordia boissieri & 234 & 409 & 23.9 & 113 & 166 & 14.1 & 6 & 1 & 7.2 \\
\hline Diospyros palmeri & 4 & 9 & 1 & * & * & * & * & * & * \\
\hline Ebenopsis ebano & 4 & 25 & 1.3 & 55 & 28 & 4.6 & * & * & * \\
\hline Ehretia anacua & * & * & * & 6 & 1 & 0.7 & 3 & 0 & 3.5 \\
\hline Foresiera angustifolia & 2 & 2 & 0.7 & * & * & * & * & * & * \\
\hline Havardia pallens & 132 & 174 & 11.5 & * & * & * & * & * & * \\
\hline Jatropha dioica & * & * & * & * & * & * & 3 & 1 & 3.7 \\
\hline Leucophyllum frutescens & 39 & 18 & 3 & 263 & 141 & 18.2 & 8 & 9 & 10.3 \\
\hline Leucaena leucocephala & * & * & * & 14 & 8.4 & 1.7 & * & * & * \\
\hline Senegalia wrightii & 37 & 30 & * & * & * & * & * & * & * \\
\hline Parkinsonia acueleata & * & * & * & 40 & 111 & 8.1 & * & * & * \\
\hline Parkinsonia texana & 201 & 346 & 19.5 & 9 & 19 & 1.9 & * & * & * \\
\hline Lantana canescens & * & * & * & 24 & 6 & 1.9 & * & * & $*$ \\
\hline Prosopis glandulosa & 22 & 218 & 7.2 & 81 & 30 & 7 & 12 & 2 & 8.3 \\
\hline Baccharis salicifolia & $*$ & $*$ & $*$ & 43 & 47 & 5.3 & * & * & $*$ \\
\hline Yucca filifera & 21 & 68 & 4.1 & * & * & * & * & * & * \\
\hline Zanthoxylum fagara & 43 & 102 & 6.2 & * & * & * & * & * & * \\
\hline Without Vegetation & & & & & & & & & 10.4 \\
\hline Total Area & 924 & 1604 & 100 & 1033 & 1116 & 100 & 70 & 125 & 100 \\
\hline
\end{tabular}

glandulosa in the vegetation community of the unassisted ecological succession area match the results of $[15,25]$ registering the species in areas that have suffered some type of disturbance due to anthropogenic activity. A. farnesiana is a pioneer species that presents a high germination rate in temperature ranges from 12 to $28{ }^{\circ} \mathrm{C}$ $[17,29,30]$ and like P. glandulosa, it is characterized by their rapid growth $[16,21]$ and its tolerance to edaphic drought which is a common characteristic of the study area. This species also has higher values in hydric potential of the xylem on the pre-dawn and in midday, under conditions of lack of water, compared to other species $[13,24]$. Its presence is also associated with low availability of nitrogen in the soil, which results in a limiting factor for other groups and an advantage for the species of this family. These aspects suggest that unfavorable habitat conditions advantage the establishment and dominance $[3,50]$, making it an important group in the initial stages of succession and suitable for restoration activities.

The plantation abundance of the assisted ecological succession was $992 \mathrm{~N} \mathrm{ha}^{-1}$, and after seven years it was
$1416 \pm 178 \mathrm{~N} \mathrm{ha}^{-1}$, which indicates that in addition to the established individuals there was a regeneration of native species. The composition of this assisted community was partly a product of the species selected for revegetation, the restoration activities, as well as of the ecological performance of the species observed at the end of the study.

The highest importance value found in A. farnesiana can be explained through some factors such as: the advantage of its ecological performance in harsh environments, the low mortality of seedlings and saplings in plantation conditions [21] and the high capacity for canopy development in plantation conditions (which also explains the higher basal area). The rapid development of the canopy can strongly limit the germination, establishment, and development of light-demanding species [22], which can, on the other hand, benefit the species tolerance to shading conditions like $C$. boissieri, that is also included in the actions of restoration, and that occupies the third value of importance in this area.

Leucophyllum frutescens, a pioneer species with the second most important value in the assisted ecological 

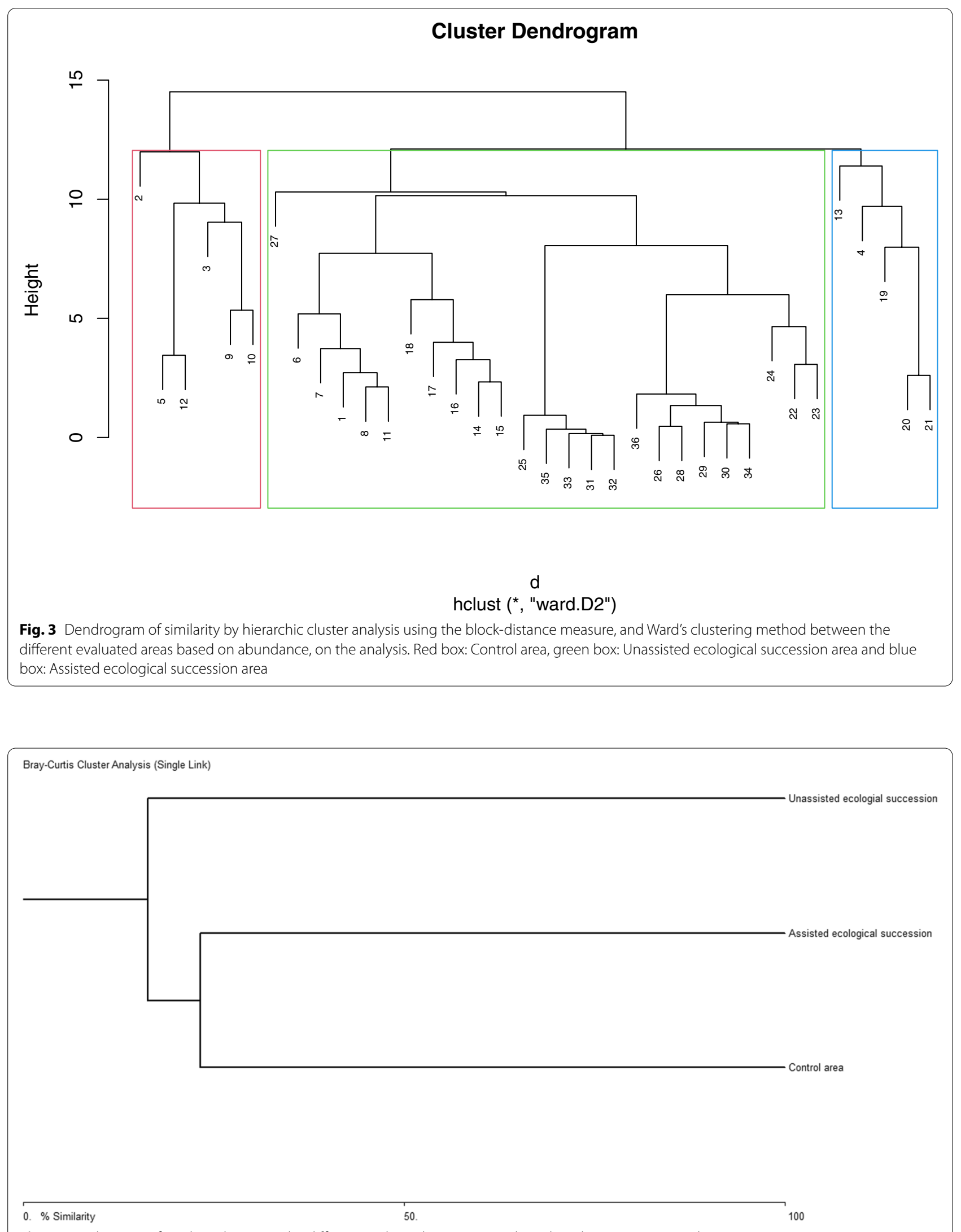

Fig. 4 Dendrogram of similarity between the different evaluated communities based on the Bray-Curtis analysis 
succession area is commonly associated with low productivity areas, which could explain the ability to withstand limiting condition areas [47]. P. glandulosa was the species found in all studied areas, alongside the tolerance to adverse environmental and edaphic conditions, show low mortality in plantations with seedlings surviving rate above 85\% [21]. However, as growing time passes, the plantations are susceptible to pest attacks, which can increase the mortality, this could explain the low importance value in the assisted ecological succession area (IVI $=7 \%$ ).

Ebenopsis ebano (Berland.) Barneby \& J.W Grimes and Acacia rigidula species of moderate growth [14, 28] presented on both control and the assisted ecological succession area. These species can withstand the stress conditions [21], which also makes them an adequate option for restoration actions.

Similar to what was reported in this study, other authors [36, 38] showed that the assisted ecological succession treatment was effective in terms of recovering the richness and diversity of tree and shrub species compared to passive restoration actions in northeastern Mexico, which explains to a large extent the similarity between the control and the assisted ecological succession site, unlike unassisted ecological succession area.

The dissimilarity in the composition of plant communities observed in our study is similar to the results recorded by Alanis et al. [3] on vegetation communities of the Tamaulipan thornscrub with a different productive use and obtained inferior values of similarity. The differences in species composition could be explained as differences in growing of the communities in control and unassisted ecological succession area, also the influence of the origin of the structure and composition of the control area compared to the assisted ecological succession area, which is strongly limited to the species which it was intervened. Additionally, the dissimilarity of the communities in our study and the study of Alanis et al. [3] can be explained through the heterogeneity of Tamaulipan thornscrub vegetation that usually shows different species composition according to the land use, topographic and edaphic conditions y differences in altitude [55].

The differences between assisted ecological succession and control area plant communities are determined by the dissimilarity of common species and high-density values. In the control area, the species are Cordia boissieri $\left(243 \mathrm{~N} \mathrm{ha}^{-1}\right)$ and Parkinsonia texana $\left(201 \mathrm{~N} \mathrm{ha}^{-1}\right)$ while in the assisted ecological succession area Acacia farnesiana $\left(374 \mathrm{~N} \mathrm{ha}^{-1}\right)$ and Leucophyllum frutescens $\left(263 \mathrm{~N} \mathrm{ha}^{-1}\right)$.

\section{Carbon stocks}

It is relevant to analyze the carbon stock in the three areas, since $\mathrm{CO}_{2}$ is the main greenhouse gas, and that plant species play a fundamental role in the absorption and fixation of carbon [67]. In this regard, the highest value of captured carbon registered for the control area and assisted ecological succession communities compared to the capture of unassisted ecological succession area is mainly attributable to the higher number of individuals and the diametric categories observed in these areas (Table 2). The unassisted ecological succession area concentrates practically all the individuals of the smaller diameter category, which is logical because to reach similar values as the control area must take several years for the development of the vegetation and the recovery of the ecological and dasometric normal parameters.

Compared to the dasometric values of the control area (mature thornscrub community), the ecological, dasometrical and C Stock variables of the assisted ecological succession shrubland area were recovered in seven years after the restoration the activities. Similar distribution pattern of the individuals in the diametric classes, and thus of $\mathrm{C}$ stocks, were observed in other successional studies of the Tamaulipan thornscrub communities, where early successional stages concentrated the individuals of the smaller diameter category and had a low $\mathrm{C}$ stock $[36,67]$. This pattern suggests that vegetation from assisted ecological succession shrubland follows an optimal growth trend [67].

\section{Conclusion}

Our results provide valuable information about the restoration and regeneration condition and structure and composition of woody plant community after seven years of assisted ecological succession treatment in a Tamaulipan thornscrub located in northeastern Mexico.

The values of species richness, diversity, abundance, basal area and canopy area of the assisted ecological succession vegetal community presented statistical equality with the control plant community.

The values of captured carbon showed that assisted ecological succession could recover not only structure and composition attributes but also this ecological service. These results indicate that the assisted ecological succession treatment was effective on recovering the richness and diversity of tree and shrub species compared to passive restoration actions in the Tamaulipan thornscrub studied.

\section{Supplementary Information}

The online version contains supplementary material available at https://doi. org/10.1186/s40693-021-00102-6.

Additional file 1: Appendix I. Scheme of the plantation process of the assisted ecological succession.

Additional file 2: Appendix II. Scheme of the plantation process of the assisted natural succession. 


\section{Acknowledgements \\ Not applicable.}

\section{Author's contributions}

EAR, VMMG, ACCC, EBR, AMO, LSC, AGAR: all authors conceived the study, designed the experiments, contributed to the data analysis, interpretation, discussion of results and writing. The author(s) read and approved the final manuscript.

\section{Availability of data and materials}

https://zenodo.org/record/5104256.

\section{Declarations}

Ethics approval and consent to participate

Not applicable.

\section{Consent for publication}

Not applicable.

\section{Competing interests}

The authors declare that they have no competing interests.

\section{Author details}

${ }^{1}$ Facultad de Ciencias Forestales, Universidad Autónoma de Nuevo León, Carretera Linares-Cd. Victoria Km 145. Apartado Postal 41, CP 67700 Linares, N. L, México. ${ }^{2}$ RENAC, S.A. de C.V, Perlitas 127, Col. Las Glorias, CP 67710 Linares, N. L, México. ${ }^{3}$ División de Desarrollo Sustentable, Universidad de Quintana Roo, Avenida Andrés Quintana Roo con calle 110 Sur s.n., CP 77600 Cozumel, Quintana Roo, México. ${ }^{4}$, Campo Experimental Valle de México (INIFAP-CEVAMEX), Instituto Nacional de Investigaciones Forestales, Agrícolas y Pecuarias, Km. 13.5 Carretera los Reyes-Texcoco. Apartado Postal 10. Coatlinchan, CP 56250 Texcoco, Estado de México, México. ${ }^{5}$ Universidad Autónoma de Tamaulipas, Instituto de Ecología Aplicada, División del Golfo 356, CP 87019 Ciudad Victoria, Tamaulipas, México. ${ }^{6}$ Facultad de Ingeniería Y Ciencias, Centro Universitario, Universidad Autónoma de Tamaulipas, CP 87120 Ciudad Victoria, Tamaulipas, México. ${ }^{7}$ Ternium México, S.A. de C.V, Universidad 992, Col. Cuauhtémoc, CP 66450 San Nicolás de los Garza, N.L, México.

Received: 25 March 2021 Accepted: 3 September 2021

Published online: 25 November 2021

\section{References}

1. Aide TM, Ruiz-Jaen MC, Grau HR. What is the state of tropical montane cloud forest restoration? In: Bruijnzeel LA, Scatena FN, Hamilton LS, editors. Tropical montane cloud forests science for conservation and management. Cambridge: Cambridge University Press; 2010. p. 101-10.

2. Alanís E, Jiménez J, Aguirre O, Treviño E, Jurado E, González M. Efecto de uso del suelo en la fitodiversidad del matorral espinoso tamaulipeco. Ciencia UANL. 2008;11(1):56-62

3. Alanís E, Jiménez J, González MA, Yerana JI, Cuellar LG, Mora-Olivo A Análisis de la vegetación secundaria del matorral espinoso tamaulipeco, México. Phyton Int J Exper Bot. 2013:82:185-91.

4. Alanís E, Molina VM, Rechy L, Alcalá AG, Marín JD, Pequeño MA. Composición, diversidad y sobrevivencia de un área restaurada en el Complejo Siderúrgico de Ternium, Pesquería, México. In: Experiencias mexicanas en la restauración de los ecosistemas. Primera edición. Cuernavaca, UNAM. 2016;255-274. ISBN: 9786078434763

5. Aronson J, Alexander S. Ecosystem restoration is now a global priority: time to roll up our sleeves. Restor Ecol. 2013;21(3):293-6. https://doi.org/ 10.1111/rec.12011.

6. Arriaga L. Implicaciones del cambio de uso de suelo en la biodiversidad de los matorrales xerófilos: un enfoque multiescalar. Investigación Ambiental. 2009;1(1):6-16.

7. Arriaga-Cabrera L, Espinoza-Rodríguez JM, Aguilar-Zúñiga C, Martínez Romero E, Gómez-Mendoza L, Loa-Loza E. Regiones terrestres prioritarias de México. Comisión Nacional para el conocimiento y uso de la biodiversidad. Mexico. 2000. ISBN: 970-9000-16-0
8. Beals EW. Bray-Curtis ordination: an effective strategy for analysis of multivariate ecological data. Adv Ecol Res. 1984;14:1-56. https://doi.org/ 10.1016/S0065-2504(08)60168-3.

9. Bray JR, Curtis JT. An ordination of the upland forest communities of Southern Wisconsin. Ecol Monogr. 1957;27:325-49. https://doi.org/10. 2307/1942268.

10. Bullock JM, Aronson J, Newton AC, Pywell RF, Rey-Benayas JM. Restoration of ecosystem services and biodiversity: conflicts and opportunities. Trends Ecol Evol. 2011;26(10):541-9. https://doi.org/10.1016/j.tree.2011. 06.011.

11. Burch DG, Will AA. Trees that know their place. Proc Florida State Horticult Soc. 1990;193:366-8.

12. Chazdon RL, Guariguata MR. Natural regeneration as a tool for large-scale forest restoration in the tropics: prospects and challenges. Biotropica. 2016;48:716-30. https://doi.org/10.1111/btp.12381.

13. Domínguez GT, González H, Ramírez R, Estrada E, Cantú I, Gómez M, Villarreal J, Alvarado S, Ivarado, Alanís G. Diversidad estructural del matorral espinoso tamaulipeco durante las épocas seca y húmeda. Revista Chapingo, Serie Ciencias Forestales y del Ambiente. 2013;4(17):106-22.

14. Elizondo R. Guía de árboles y otras plantas nativas en la zona metropolitana de Monterrey. Monterrey: Fondo Editorial de Nuevo León; 2009. p. 320.

15. Estrada E, Yen AD, Villarreal J. Leguminosas del centro del estado de Nuevo León, México. Anales del Instituto de Biología, Universidad Nacional Autónoma de México. Serie Botanica. 2004;75:73-85.

16. Ewing $\mathrm{K}$, Best $\mathrm{C}$. South Texas tamaulipan thornscrub restoration experiment measures growth of planted woody vegetation. Ecol Restor. 2004:22(1):11-7.

17. Flores J, Jurado E. Germination and early growth traits of 14 plant species native to Northern Mexico. Southwesthern Natur . 1998;43(1):40-6.

18. Foroughbakhch R, Maginot NH. Structure and Floristic Composisions of Ecosystems of Northeast of Mexico. Chron Bioresour Manage. 2017;1(2):060-4.

19. Foroughbakhch R, Alvarado-Vázquez MA, Carrillo Parra A, HernándezPiñero JL, Guzmán Lucio MA. Floristic diversity of a shrubland in northeastern Mexico. Phyton. 2013;82:175-84.

20. Foroughbakhch R, Carrillo Parra A, Hernández Piñero JL, Alvarado Vázquez MA, Rocha Estrada A, and Cardenas ML. Wood volume production and use of 10 woody species in semiarid zones of Northeastern Mexico. Int Forestry Res 2012;1-7. doi:https://doi.org/10.1155/2012/529829

21. Foroughbakhch R, Hernández-Piñero JL, Carrillo-Parra A. Adaptability, growth and firewood volume yield of multipurpose tree species in semiarid regions of Northeastern Mexico. Int J Agric Policy Res. 2014;2(12):444-53. https://doi.org/10.15739/IJAPR.016.

22. Foroughbakhch R. Establishment and growth potential of fuelwood species in northeastern Mexico. Agrofor Syst. 1992;19:95-108. https://doi. org/10.1007/BF00138500.

23. García E. Modificaciones al sistema de clasificación climática de Köppen. México: Instituto de Geografía, UNAM; 1964.

24. González-Rodríguez H, Cantú I, Ramírez RG, Gómez MV, Pando M, López JM. Potencial hídrico xilemático en cuatro especies arbustivas nativas del noreste de México. Revista Chapingo Serie Ciencias Forestales y del Ambiente. 2011;17:97-109. https://doi.org/10.5154/r.rchscfa.2010.09.080.

25. Jiménez J, Alanís E, González MA, Aguirre OA, Treviño EJ. Characterizing regeneration of woody species in areas with different land-history tenure in the Tamaulipan thornscrub Mexico. Southwestern Natur. 2013;58(3):299-304. https://doi.org/10.1894/0038-4909-58.3.299.

26. Jones HP, Jones PC, Barbier EB, Blackburn RC, Rey Benayas JM, Holl KD, Mateos DM. Restoration and repair of Earth's damaged ecosystems. Proc Royal Soc B: Biol Sci. 2018;285(1873):20172577. https://doi.org/10.1098/ rspb.2017.2577.

27. Jurado E, Aguirre O, Flores J, Návar J, Villalón H, Wester D. Germination in tamaulipan thornscrub of north-eastern Mexico. J Arid Environ. 2000;46:413-24. https://doi.org/10.1006/jare.2000.0684.

28. Jurado E, Estrada E, Moles A. Characterizing plant attributes with particular emphasis on seeds in Tamaulipan thornscrub in semi-arid Mexico. J Arid Environ. 2001:48:309-21. https://doi.org/10.1006/jare.2000.0762.

29. Jurado E, Návar JH, Villalón H, Pando M. Germination associated with season and sunlight for Tamaulipan thornscrub plants in north-eastern Mexico. J Arid Environ. 2001;49:833-41. https://doi.org/10.1006/jare.2001.0817.

30. Lindig-Cisneros R. Ecological restoration in Mexico: the challenges of a multicultural megadiverse country. Ecol Restor. 2010;28(3):232-3. 
31. Lohbeck M, Poorter L, Martínez-Ramos M, Rodríguez-Velazquez J, van Breugel $M$, Bongers F. Functional ecology changing drivers of species dominance during tropical forest succession. Funct Ecol. 2014;28(4):1052-8. https://doi.org/10.1111/1365-2435.12240.

32. López-Barrera F, Martínez-Garza C, Ceccon E. Ecología de la restauración en México: estado actual y perspectivas. Revista Mexicana de Biodiversidad. 2017;88:97-112. https://doi.org/10.1016/j.rmb.2017.10.001.

33. Maiti R, González R, Kumari CA. Wood carbon and nitrogen of 37 woody shrubs and trees in Tamaulipan thorn scrub, Northeastern Mexico. Pakistan J Bot. 2019;51(3):979-84. https://doi.org/10.30848/PJB2019-3(25).

34. Marañón T, Grubb PJ. Physiological basis and ecological significance of the seed size and relative growth rate relationship in Mediterranean annuals. Funct Ecol. 1993;7:591-9. https://doi.org/10.2307/2390136.

35. Marroquín-Castillo JJ, Alanís-Rodríguez E, Jiménez-Pérez J, Aguirre-Calderón OA, Mata-Balderas JM, Rubio-Camacho EA, Chávez-Costa AC. Composición florística y diversidad de un área restaurada post-minería en el matorral espinoso tamaulipeco. Acta Botánica Mexicana. 2017;120:7-20. https://doi. org/10.18387/polibotanica.42.1.

36. Martínez DD, Alanís E, Jiménez J, Yerena Jl, Gómez MM. Contenido de carbono en un sistema agroforestal pastorilsilvícola del matorral espinoso tamaulipeco. Ciencia UANL. 2015;18(74):58-62.

37. Mata M, Treviño EJ, Jiménez J, Aguirre OA, Alanís E, Foroughbakhch R. Prácticas de rehabilitación en un ecosistema semiárido afectado por e establecimiento de un banco de material, en el noreste de México. Ciencia UAT. 2014;8(2):32-43.

38. McAleece N, Lambshead J, Paterson GL, and Gage JD. BioDiversity pro, Version 2. The Natural History Museum, London, and The Scottish Association of Marine Science, Oban, Scotland. 1997.

39. Meli P, Holl KD, Rey Benayas JM, Jones HP, Jones PC, Montoya D. and Moreno Mateos D. A global review of past land use, climate, and active vs. passive restoration effects on forest recovery. Plos one, 2017;12(2). https://doi.org/ 10.1371/journal.pone.0171368

40. Mora CA, Alanís E, Jiménez J, González MA, Yerena Jl, Cuellar LG. Estructura, composición florística y diversidad del matorral espinoso tamaulipeco, México. Ecología Aplicada. 2013;12(1):29-34.

41. Moreno CE. Métodos para medir la biodiversidad. M\&T Manuales y Tesis SEA España. 2001;1:84

42. Morrison EB, Lindell CA. Active or passive forest restoration? Assessing restoration alternatives with avian foraging behavior. Restor Ecol. 2010;19(201):170-7. https://doi.org/10.1111/j.1526-100X.2010.00725.x

43. Mostacedo B and Fredericksen TS. Manual de Métodos Básicos de Muestreo y Análisis en Ecología Vegetal. Proyecto de Manejo Forestal Sostenible. Santa Cruz de la Sierra. 2000.

44. Mueller-Dombois D, Ellemberg H. Aims and methods of vegetation ecology. New York: Wiley; 1974

45. Návar J, Mendez E, Graciano J, Dale V, Parresol B. Biomass equations for shrub species of Tamaulipan thornscrub of northeastern Mexico. J Arid Environ. 2004;59:657-74. https://doi.org/10.1006/jare.2001.0819.

46. Návar JF, Rodríguez-Flores J, Dominguez-Calleros PA, Pérez-Verdin G. Diversity-productivity relationship in the northeastern tamaulipan thornscrub forest of Mexico. Int J Ecol. 2010;1:11. https://doi.org/10.1155/2014/196073.

47. Ngangyo M, Foroughbakhch R, Carrillo-Parra A, Lidia-Rosaura SC. Estimation of timber production of five species of the tamaulipas thorny shrubs growing in native stands and plantations. Open J Forestry. 2014;4(3):239. https:// doi.org/10.4236/ojf.2014.43031.

48. Ngangyo-Heya M, Foroughbakhch-Pournavab R, Carrillo-Parra A, Salas-Cruz LR, Alvarado-Vázquez MA, Bustamante-García V. Foliar biomass production and litterfall pattern of five timber species in forest plantations of semi-arid lands of the northeastern Mexico. Bot Sci. 2017;95(2):295-305. https://doi. org/10.17129/botsci.770.

49. Panshin AJ, Zeeuw CD. Textbook of Wood Technology. 4th ed. New York: McGraw-Hill; 1980

50. Pequeño LM, Alanís E, Jiménez J, González MA, Yerena I, Cuellar LG, Mora A. Análisis de la restauración pasiva post-pecuaria en el matorral espinoso tamaulipeco del noreste de México. Ciencia UAT. 2012;24(2):48-53.

51. Pequeño-Ledezma MA, Alanís-Rodríguez E, Jiménez-Pérez J, González-Tagle MA, Yerena-Yamallel Jl, Cuellar-Rodríguez LG, Mora-Olivo A. Análisis de la restauración pasiva post-pecuaria en el matorral espinoso tamaulipeco del noreste de México. Ciencia UAT. 2012;4(2):48-53.
52. Pickett STA, McDonnell MJ. Changing perspectives in community dynamics: a theory of successional forces. Trends Ecol Evol. 1989;8(4):241-5. https://doi. org/10.1016/0169-5347(89)90170-5.

53. Pontifes PA, García-Meneses PM, Gómez-Aíza L, Monterroso-Rivas Al, CasoChávez M. Land use/land cover change and extreme climatic events in the arid and semi-arid ecoregions of Mexico. Atmósfera. 2018;31(4):355-72. https://doi.org/10.20937/ATM.2018.31.04.04

54. R core Team . RStudio: Integrated Development for R. Boston, MA: RStudio, Inc. 2015. Available from: http://www.rstudio.com/

55. Reid N, Stafford Smith DM, Beyer-Münzel P, Marroquín J. Floristic and structural variation in the Tamaulipan thornscrub, northeastern Mexico. J Veg Sci. 1990;1:529-38. https://doi.org/10.2307/3235787.

56. Rey Benayas JM, Barral MP, Meli P. Lecciones de cuatro meta-análisis globales sobre la restauración de la biodiversidad y los servicios ecosistémicos. Ecol Austral. 2017;27:193-8. https://doi.org/10.25260/EA.17.27.1.1.252.

57. Ruwanza S, Gaertnera M, Eslera KJ, Richardson DM. The effectiveness of active and passive restoration on recovery of indigenous vegetation in riparian zones in the Western Cape, South Africa: A preliminary assessment. S Afr J Bot. 2013;88:132-41. https://doi.org/10.1016/j.sajb.2013.06.022.

58. Sanchez-Castillo L, Kosugi K, Masaoka N, Kubota T. Eco-morphological characteristics of fern species for slope conservation. J Mountain Sci. 2019;16:504-15. https://doi.org/10.1007/s11629-018-5106-z.

59. Sarmiento-Muñoz TI, Alanís-Rodríguez E, Mata-Balderas JM, Mora-Olivo A. Estructura y diversidad de la vegetación leñosa en un área de matorral espinoso tamaulipeco con actividad pecuaria en Nuevo León. México CienciaUAT. 2019;14(1):31-44.

60. Secretaría de Programación y Presupuesto (SPP). 1983. Síntesis Geográfica del Estado de Tamaulipas. Instituto Nacional de Estadística, Geografía e Informática. México, D.F. 158 pp. Available from: http://internet.contenidos. inegi.org.mx/contenidos/productos/prod_serv/contenidos/espanol/bvine gi/productos/historicos/2104/702825220822/702825220822_1.pdf

61. SERI. The SER International Primer on Ecological Restoration. URL http:// www.ser.org. 2006.

62. Shannon CE. A mathematical theory of communication. Bell Syst Techn J. 1948;27(379-423):623-56

63. Society of Ecological Restoration. Principios de SER Internacional sobre restauración ecológica. Available from: http://www.ser.org/content/guide lines_ecological_restoration.asp

64. Tobón WT, Urquiza-Haas P, Koleff M, Schröter R, Ortega-Álvarez J, Campo R, Lindig-Cisneros J, Sarukhán AB. Restoration planning to guide Aichi targets in a megadiverse country. Conserv Biol. 2017;31(5):1086-97. https://doi.org/ 10.1111/cobi.12918

65. Vega-López JA, Alanís-Rodríguez E, Molina-Guerra VM, Buendía-Rodríguez E. Selección de especies arbóreas y arbustivas para la restauración del matorral espinoso tamaulipeco. Aridociencia. 2017;2(1):3-10.

66. Wilson SJ, Rhemtulla JM. Acceleration and novelty: community restoration speeds recovery and transforms species composition in Andean cloud forest. Ecol Appl. 2016;26:203-18. https://doi.org/10.1890/14-2129.

67. Yerena Jl, Jiménez J, Alanís E, Aguirre OA, González MA, Treviño EJ. Dinámica de la captura de carbono en pastizales abandonados del noreste de México. Trop Subtrop Agroecosyst. 2014;17:113-21.

68. Yerena-Yamallel Jl, Jiménez-Pérez J, Aguirre-Calderón OA, Treviño-Garza EJ. Concentración de carbono en la biomasa aérea del matorral espinoso tamaulipeco. Revista Chapingo Serie Ciencias Forestales y del Ambiente. 2011;17:283-91.

69. Zar JH. Biostatistical analysis. 5th ed. New Jersey: Prentice Hall; 2010. p. 663.

\section{Publisher's Note}

Springer Nature remains neutral with regard to jurisdictional claims in published maps and institutional affiliations. 